\title{
EVALUATION OF THE DWPF CHEMICAL PROCESS CELL SAMPLE CONDENSER IN THE INTEGRATED DWPF MELTER SYSTEM (U)
}

by J.R. Zamecnik

Westinghouse Savannah River Company

Savannah River Site

WSRC-TR--92-255

Aiken, South Carolina 29808

DE93 002160

This paper was prepared in connection with work done under Contract No. DE-AC09-89SR18035 with the U.S. Department of Energy. By acceptance of this paper, the putlisher and/or recipient acknowledges the U.S. Government's right to retain a nonexclusive, royalty-free license in and to any copyright covering this paper, along with the right to reproduce and to authorize others to reproduce all or part of the copyrighted paper. 


\section{DISCLAIMER}

This report was prepared as an account of work sponsored by an agency of the United States Government. Neither the United States Government nor any agency thereof, nor any of their employees, makes any warranty, express or implied, or assumes any legal liability or responsibility for the accuracy, completeness, or usefulness of any information, apparatus, product, or process disclosed, or represents that its use would not infringe privately owned rights. Reference herein to any specific commercial product, process, or service by trade name, trademark, manufacturer, or otherwise does not necessarily constitute or imply its endorsement, recommendation, or favoring by the United States Government or any agency thereof. The views and opinions of authors expressed herein do not necessarily state or reflect those of the United States Government or any agency thereof.

This report has been reproduced directly from the best available copy.

Available to DOE and DOE contractors from the Office of Scientific and Technical Information, P.O. Box 62, Oak Ridge, TN 37831; prices available from (615) 576-8401, FTS 626-8401.

Available to the 1 wblic from the National Technical Information Service, U.S. Department of Commerce, 5285 Port Royal Rd., Springfield, VA 22161. 
Keywords: DWPF, IDMS, Hydrogen, Sample Condenser

Retention: Permanent May 15, 1992

CC: I. M. Papouchado, 773-A

M. J. Plodinec, 773-A

L. F. Landon, 704-T

Process Modeling and Control Group (10)

E. W. Holtzscheiter, 773-A

C. T. Randall, 704-T

Process Technology and Development Group

Glass Technology Group (8)

Large Scale Experimentation Group

TNX Operations Section (4)

SRL Records (4)

To: J. T. Carter, 704-1T

From: J. R. Zamecnik Gf $2>$

EVALUTION OF THE DWPE CHEMICAL PROCESS CELI SAMPLE CONDENSER IN THE

INTEGRATED DWPF MELTER SYSTEM (U)

\section{INTRODUCTION}

An on-line analysis system for hydrogen is being added to the Chemical processing Cell (CPC) in DWPF to ensure that the process does not operate above the lower flammable limit (LFI). The method chosen to measure hydrogen during cold runs is gas chromatography (GC) .

In order for the GCs to analyze the offgas exiting the SRAT and SME condensers, ar additional condenser is required to reduce the dew point of the sample to below the lowest ambient temperature expected so that no liquid water will enter the GCs. This temperature was chosen to be $10^{\circ} \mathrm{C}$.

\section{FOUIPMFNT DFSCRIPTION}

A design for the condenser in DWPF was transmitted to SRTC from the Bechtel design engineer. The design includes a 7 foot long 1 " schedule $10 \mathrm{~s}$ pipe through which the sample travels. This pipe is jacketed by a 1.5" schedule 40 s pipe through which chilled water at $4-5^{\circ} \mathrm{C}$ is circulated. The design flowrate for the cooling water is 1 gpm and the design flowrate for the gas sample is $1 \mathrm{cfm}$. Upon leaving the condenser tube, the gas sample then passes through a high efficiency mist eliminator (HEME) filter 4 " in diameter and $\approx 4$ " long.

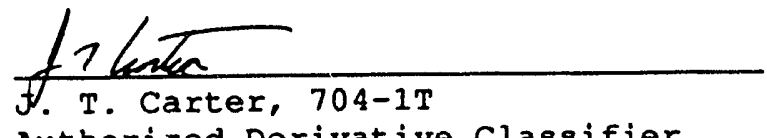

Authorized Derivative Classifier

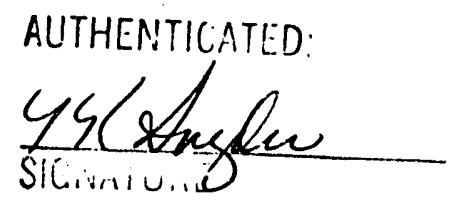


This configuration is shown in Figure 1. In DWPE, two HEPA filters will also be included after the HEME, but these were not included in IDMS .

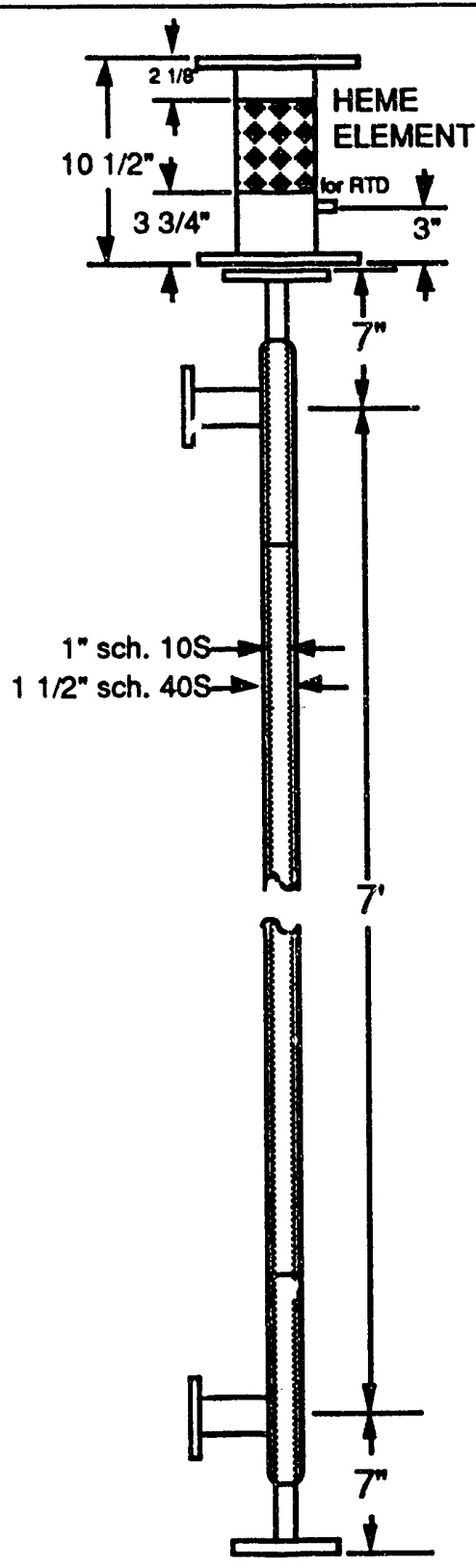

Figure 1. DWPF Prototypic sample Condenser (IDMS Installation)

The HEME filter was included since it was expected that the condensed water may form an aerosol; including the HEME would be more prototypic since the aerosol would be coalesced and would drip back down onto the condenser tube, thus affecting its performance. The DWPF design called for a HEME material from CECO Filters, Inc. 
However, none of this material was readily available. In its place, FAVC HEME material (Monsanto Environmental) packed to 15-20 $1 \mathrm{~b} / \mathrm{ft}^{3}$ was used. CECO indicated that this packing density of the FAVC HEME material would perform similarly to their material.

Figure 2 shows the installation of the sample condenser in the IDMS. The sample is drawn upward through the sample condenser and HEME by a diaphragm pump. The exhaust from the pump is then returned to the process line downstream of the inlet. The HEME housing is equipped with an RTD (resistance temperature device). The sample and cooling water flows were measured by rotameters.

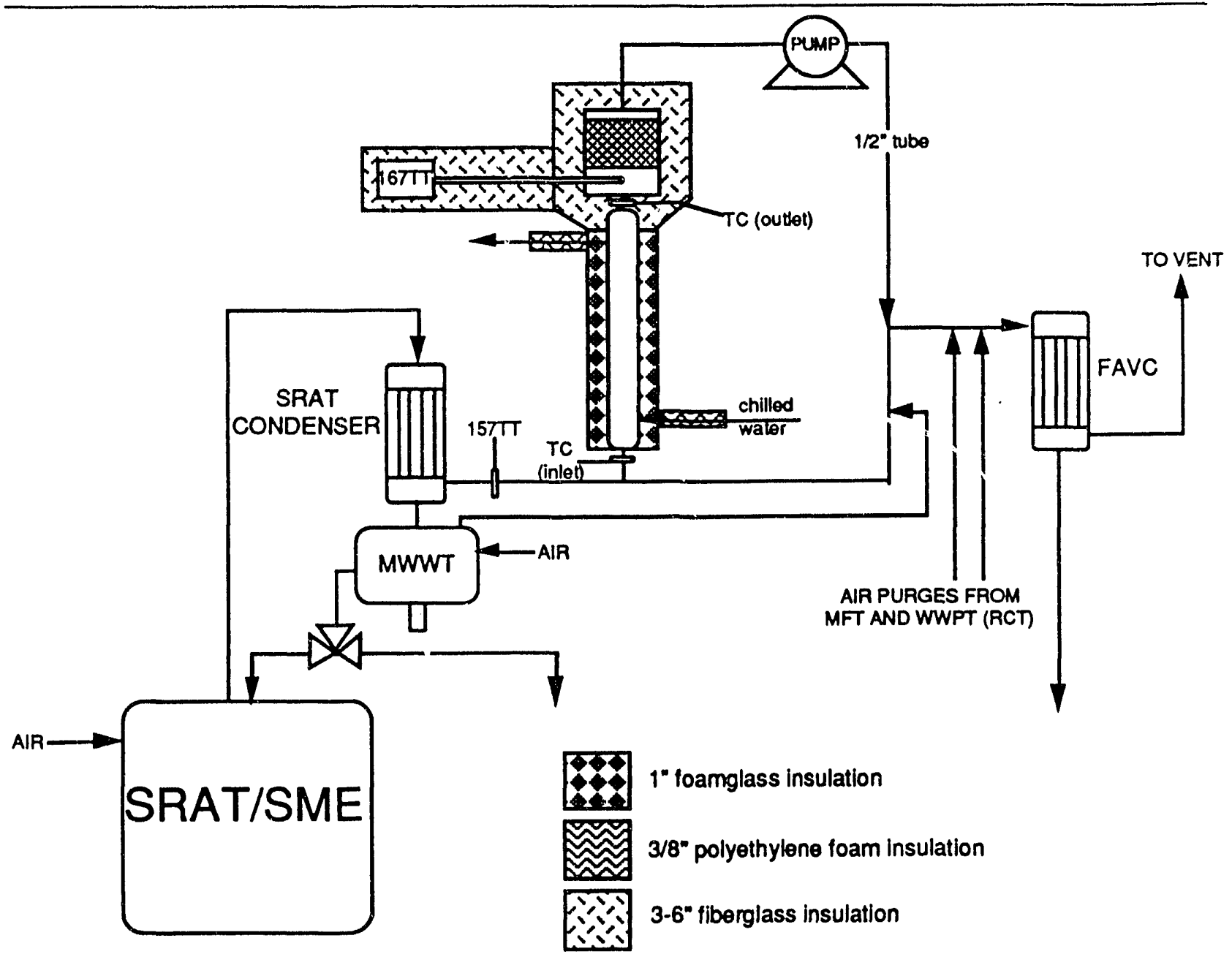

Figure 2. Sample Condenser Installation in IDMs.

\section{BESUTTS}

Initially, only the sample condenser itself and the cooling water lines were insulated. Figure 3 shows the performance of the sample condenser during the nitric acid addition and reflux during the IDMS HM4 run. The inlet temperature was approximately that shown for the SRAT/SME condenser exit. 


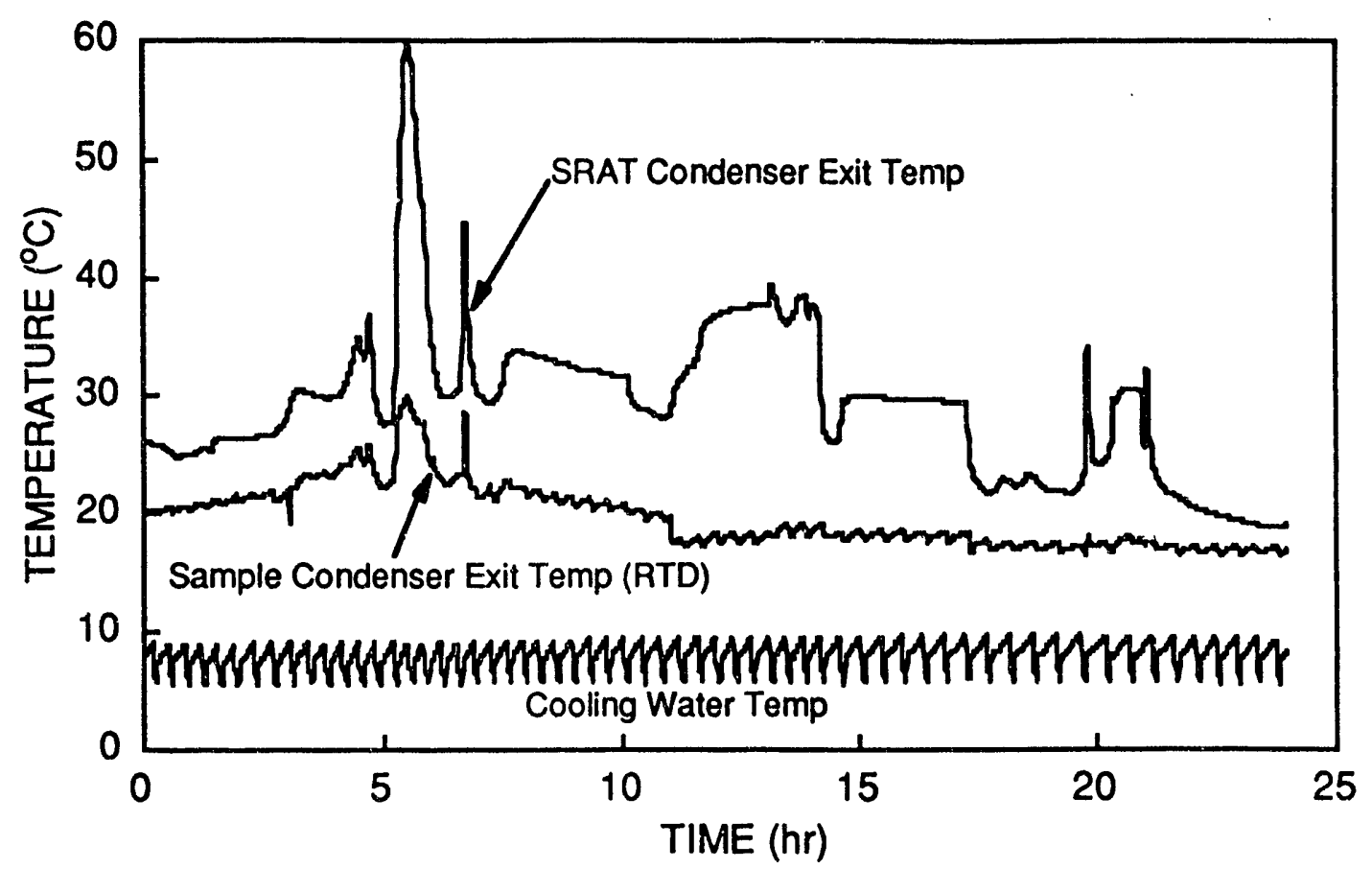

Figure 3. Sample Condenser Performance During Nitric Acid Addition and Reflux

The sample condenser shows the same type of response to $\mathrm{NO}_{x}$ that the Formic Acid Vent Condenser (FAVC) shows. The condenser inlet temperature peaks due to the reaction of $\mathrm{NO}$ with $\mathrm{O}_{2}$, resulting in decreased performance of the condenser. Moreover, this reaction also occurs inside the condenser, further decreasing its performance.

At about 12 hours it was determined that the cooling water flow was fluctuating between $0.5-1.0 \mathrm{gpm}$, and it was increased to about 1.2 $\mathrm{gpm}$, where it remained steady. At this point the performance of the condenser improved slightly, with the exit temperature stabilizing at about $17-18^{\circ} \mathrm{C}$. This temperature is $7-8^{\circ} \mathrm{C}$ above the design. However, the average cooling water temperature was $7.9^{\circ} \mathrm{C}$. A cooling water temperature of $5^{\circ} \mathrm{C}$ would have resulted in a lower sample temperature, but it still would probably have been above the design by $4-5^{\circ} \mathrm{C}$.

It was suspected that the RTD temperature measurement was in error due to conduction of heat from the surroundings, which were at $>35^{\circ} \mathrm{C}$. Insulation was added to the HEME housing and to the RTD sheath and junction box. Figure 4 (during the SME cycle) shows that the effect on the RTD reading of the added insulation was negligible. 


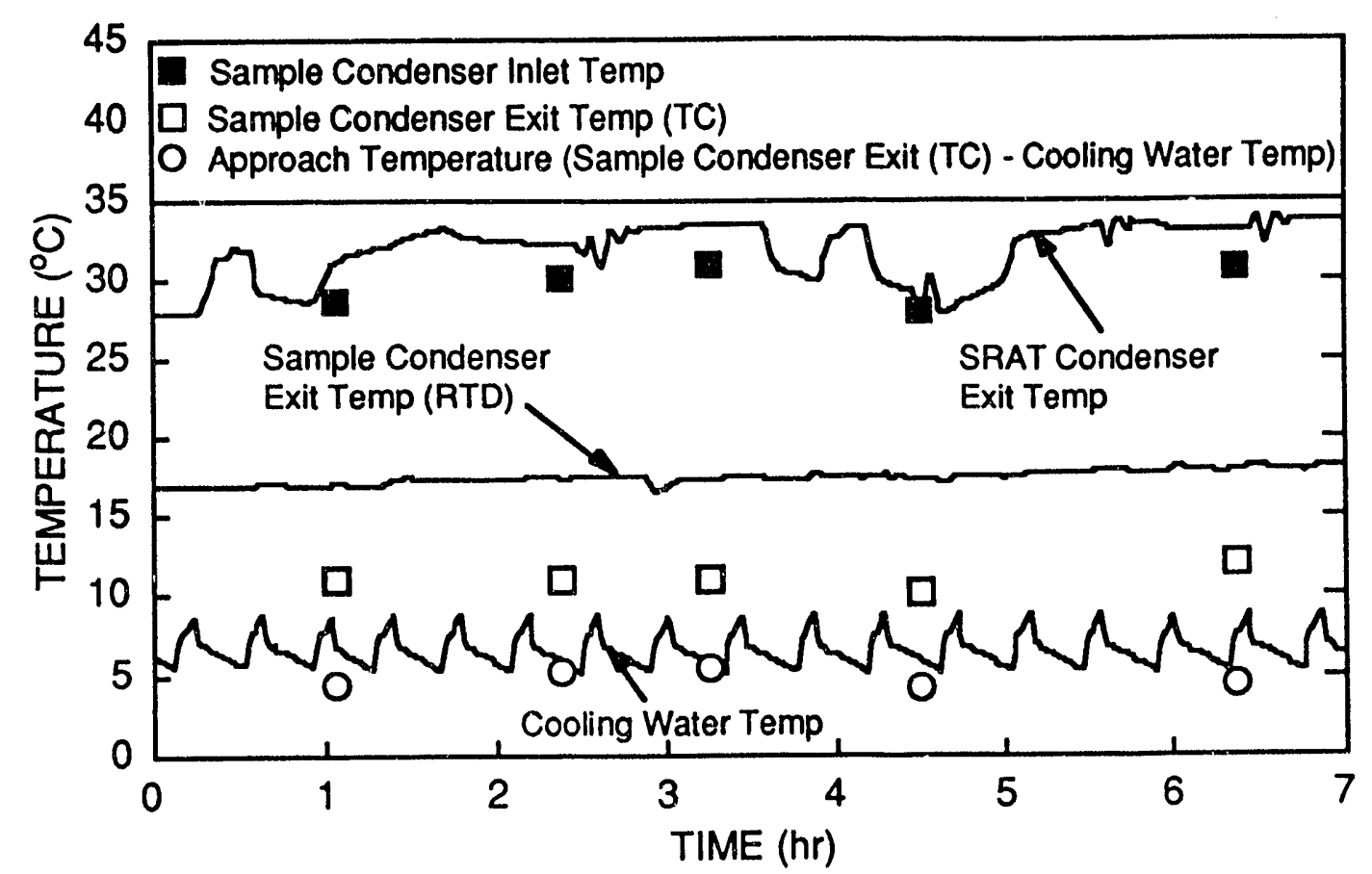
Figure 4. Sample Condenser Performance During the SME
Cycle.

In addition to adding insulation, bare-wire thermocouples were added to the entrance and exit of the condenser, as shown in Figure 2 . The readings from these thermocouples indicate that the actual inlet temperature to the sample condenser was slightly lower than at the SRAT/SME condenser exit. More dramatically, the thermocouple at the sample condenser exit showed that the RTD was reading $6-7^{\circ} \mathrm{C}$ too high. The probable reason for the high temperature is that the velocity of the sample gas in the HEME housing was so low that the heat transfer was poor. The velocity was approximately $11.5 \mathrm{ft} / \mathrm{min}$, compared to process velocities of $\approx 150 \mathrm{ft} / \mathrm{min}$. The average cooling water temperature during these data was $6.6^{\circ} \mathrm{C}$ and the approach temperature was $4-5^{\circ} \mathrm{C}$, based on the thermocouple readings. If the cooling water temperature had been $4-5^{\circ} \mathrm{C}$, the sample exit temperature may have dropped to as low as $8-10^{\circ} \mathrm{C}$, which would meet the design criteria.

The previous data were all taken with SRAT/SME condenser exit temperatures much lower than the DWPF design values $\left(\approx 30^{\circ} \mathrm{C}\right.$ compared to $50^{\circ} \mathrm{C}$ ). In order to better test the sample condenser, the SRAT/SME was refluxed at a steam rate of $700 \mathrm{ib} / \mathrm{hr}$, which resulted in SRAT/SME exit temperatures of $45-60^{\circ} \mathrm{C}$. Figure 5 shows these data. Under these conditions, the RTD and thermocouple readings were consistent, with the exit temperature ranging from $15-19^{\circ} \mathrm{C}$. Given an average cooling water temperature of $7.4^{\circ} \mathrm{C}$, the approach temperature varied from 5.6-11. $8^{\circ} \mathrm{C}$. With cooling water at $5^{\circ} \mathrm{C}$, the sample condenser exit temperature would have been $10.6-16.8^{\circ} \mathrm{C}$. 


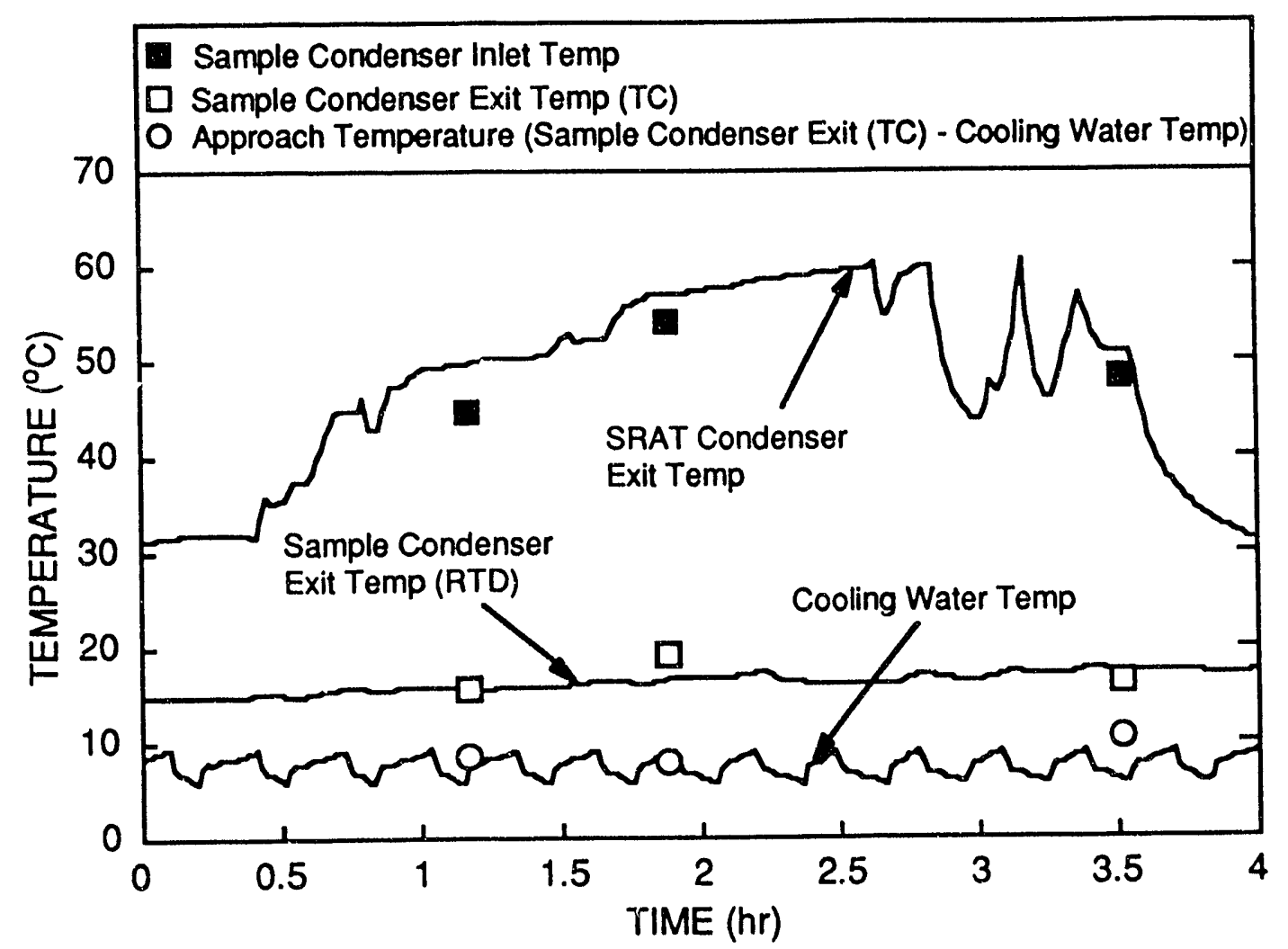

Figure 5. Sample Condenser Performance During the SME Cycle at $700 \mathrm{lb} / \mathrm{hr}$ steam.

\section{CONCIUSIONS}

Although the condenser did not meet the design requirements under all conditions, the design is still probably sufficient since the only true requirement for the condenser is to reduce the sample temperature below the lowest ambient temperature. The lowest ambient in DWPF is likely to be no less than $20^{\circ} \mathrm{C}$.

The temperature measurements with the RTD proved to be inaccurate when compared with the direct contact thermocouple. It is recommended that a thermocouple or RTD designed to reduce ambient heat conduction be used.

Since this work was completed, Bechtel has decided to change the design of the condenser from upflow with cocurrent cooling water flow to downflow with countercurrent cooling water flow. It will not be possible to test this new configuration in IDMS. 


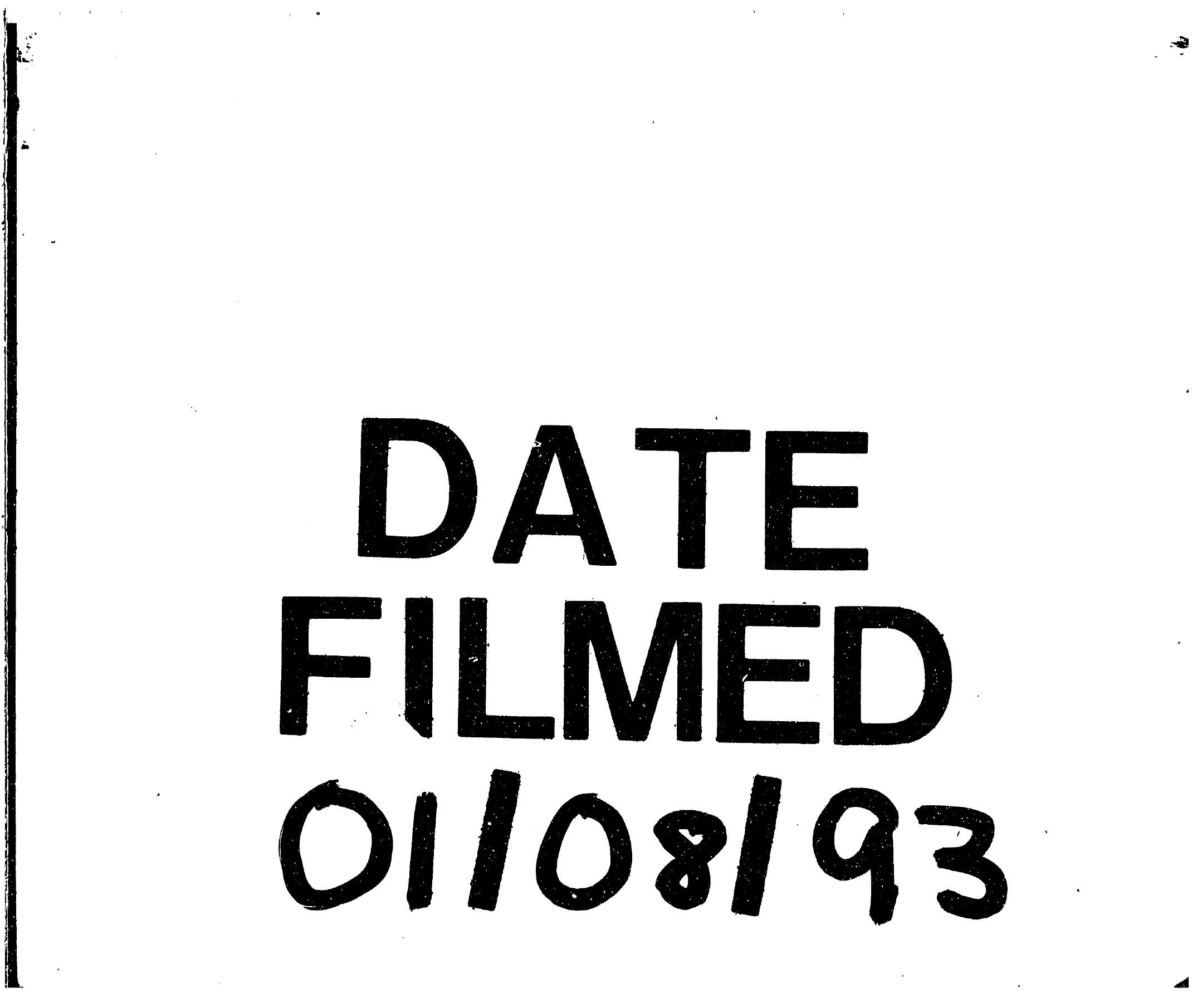


